\title{
CROSS-BORDER E-COMMERCE WZDŁUŻ CYFROWEGO JEDWABNEGO SZLAKU
}

Celem artykułu jest przedstawienie możliwie najbardziej kompleksowych informacji na temat międzynarodowego handlu elektronicznego (cross-border e-commerce), jak również Cyfrowego Jedwabnego Szlaku (Digital Silk Road) jako części planu rewitalizacji starożytnego Jedwabnego Szlaku oraz nowego procesu globalizacji. Przedstawione tu informacje stanowia fragment moich obszernych badań nad wpływem globalnego handlu elektronicznego wzdłuż Cyfrowego Jedwabnego Szlaku na ułatwienie handlu międzynarodowego. Cyfrowy Jedwabny Szlak może być rozumiany jako platforma promująca nieskrępowany rozwój globalnego e-handlu, a także wspierająca biznesy w procesie przekształcenia działalności z tradycyjnej na elektroniczną m.in. poprzez konstrukcję kluczowej infrastruktury, która przyczynia się do ułatwienia połączeń zarówno fizycznych, jak i cyfrowych pomiędzy krajami uczestniczacymi w inicjatywie. Współpraca w ramach Cyfrowego Jedwabnego Szlaku opiera się na tych samych zasadach co inicjatywa Pasa i Szlaku. Są to: pokój i współpraca, otwartość i inkluzywność, wzajemna nauka i wzajemne korzyści.

W artykule staram się z jednej strony odpowiedzieć na pytanie, czym jest Cyfrowy Jedwabny Szlak, a z drugiej, w jaki sposób wiąże się on z międzynarodowym handlem elektronicznym. Rozważania snuję też wokół innych istotnych pytań. Na czym skupia się Cyfrowy Jedwabny Szlak? Jak Cyfrowy Jedwabny Szlak powiązany jest z inicjatywą Pasa i Szlaku? Czy istnieje relacja pomiędzy globalnym handlem elektronicznym i Cyfrowym Jedwabnym Szlakiem? Jeśli tak, to w jaki sposób oba elementy wzajemnie na siebie wpływają?

W odpowiedzi na te pytania poddałam dokładnej analizie liczne źródła, m.in. literaturę naukowa, publikacje internetowe, badania naukowe oraz statystyki. Wiele informacji pozyskałam za pośrednictwem Internetu, który notabene w ogromnym stopniu przyczynił się do rozwoju zarówno globalnego e-handlu, jak i Cyfrowego Jedwabnego Szlaku. Niemniej, mając na uwadze powszechny dostęp do światowej rozległej sieci internetowej (World Wide Web) oraz różna genezę publikowanych materiałów, informacje pozyskane on-line weryfikowałam, porównując z rzetelnymi źródłami, takimi jak oficjalne raporty, publikacje lub rządowe portale. Problemy poruszane w poniższym artykule są bardzo aktualne i znajduja się w fazie dynamicznego rozwoju. Dlatego też wiele najnowszych informacji pozyskałam poprzez dokładną analizę ostrożnie 
wybranych, wiarygodnych publikacji w mediach oraz na oficjalnych rządowych portalach internetowych. Rozwój inicjatywy Pasa i Szlaku omawiam do momentu, w którym połączyła się ona z gospodarką cyfrowa, owocując powstaniem cyfrowej odnogi projektu, a mianowicie Cyfrowego Jedwabnego Szlaku. Ponadto zaprezentowałam relację transgranicznego handlu elektronicznego z Cyfrowym Jedwabnym Szlakiem, jak również wyzwania, które stanęły przed przedsiębiorcami rozpoczynającymi e-biznes. Co więcej, przeanalizowane materiały pozwoliły na ustalenie istnienia komplementarności pomiędzy globalnym e-handlem i Cyfrowym Jedwabnym Szlakiem w aspekcie ułatwiania handlu międzynarodowego.

Warto podkreślić, że jak dotąd nie została opublikowana żadna praca badająca globalny handel elektroniczny wzdłuż Cyfrowego Jedwabnego Szlaku oraz wpływ obu elementów w procesie handlu międzynarodowego. Jest to również pierwszy tekst zawierający analizę rozwoju Alibaba Group oraz prezentujący jej związek z Cyfrowym Jedwabnym Szlakiem. Poniższy artykuł może przyczynić się do zachęcenia większej liczby przedsiębiorców do uczestnictwa w globalny handlu elektronicznym i czerpania korzyści z globalizacji gospodarki. Może też być rozumiany jako wstęp do dalszych badań nad Jedwabnym Szlakiem oraz globalnym e-handlem.

\section{Cyfrowy Jedwabny Szlak}

Inicjatywa Pasa i Szlaku (The Belt and Road Initiative) została po raz pierwszy przestawiona na arenie międzynarodowej przez przewodniczącego Xi Jinpinga podczas wizyty w Kazachstanie we wrześniu 2013 r. W swoim przemówieniu na Uniwersytecie Nazarbayev wspomniał, że Chiny i Azja Centralna powinny wspólnie budować Ekonomiczny Pas Jedwabnego Szlaku w duchu starożytnego szlaku, a mianowicie bazując na pokoju i współpracy, otwartości i inkluzywności, wzajemnej nauce i wzajemnych korzyściach. Miesiąc później przewodniczący Xi przemówił przed Parlamentem w Indonezji, apelując o podjęcie kroków w kierunku promowania współpracy pomiędzy krajami ASEAN w budowie Morskiego Jedwabnego Szlaku XXI wieku ${ }^{1}$. Dwie strategiczne wizje przedstawione przez przewodniczącego Chin są znane pod łączną nazwą jako Pas i Szlak. Aktualny i przyszły rozwój inicjatywy można podzielić na trzy fazy: faza 1: mobilizacja (2013-2016), faza 2: planowanie (2016-2021) oraz faza 3: implementacja (2021-2049)². W skrócie strategiczna inicjatywa dąży do poprawy i ułatwienia połączeń off-line oraz on-line pomiędzy Azją,

1 Treść przemówienia przewodniczącego Xi Jinpinga przed parlamentem Indonezji, 2013, s. 2-3. Asean-china-center.org, http://www.asean-china-center.org/english/2013-10/03/c_133062675.htm (dostęp: 23.01.2019),

2 S. Deorukhkar, Le Xia, China: One Belt One Road - Progress and Prospects, BBVA Research, 2017, s. 2. 
Europa, Afryka, Oceanią oraz Amerykami. W związku z tym uwaga jest skupiona głównie na konstrukcji międzynarodowej infrastruktury transportowej, takiej jak drogi, koleje czy porty, ale również na usprawnieniu cyfrowego połączenia wzdłuż Pasa i Szlaku. W dłuższej perspektywie inicjatywa Pasa i Szlaku może prowadzić do ułatwienia handlu światowego, a w efekcie również do zwiększenia obrotów. Jak wynika z zebranych danych, redukcja kosztów handlu pomiędzy uczestnikami inicjatywy, zwiazana m.in. z rozwojem infrastruktury, pozytywnie wpłynie na wzrost obrotów handlowych pomiędzy tymi krajami. Szacuje się, że w rezultacie handel międzynarodowy może wzrosną́ nawet o $12 \%$, przy jednoczesnym znaczącym obniżeniu jego kosztów ${ }^{3}$.

Niżej pokrótce omówiłam przebieg kolejnych faz inicjatywy.

Faza 1: mobilizacja (2013-2016). Od ogłoszenia inicjatywy w 2013 r. Rząd Chińskiej Republiki Ludowej nieprzerwanie promuje nowe narodowe oraz międzynarodowe dwustronne i wielostronne projekty, głównie skierowane na rozwój infrastruktury pomiędzy państwami członkowskimi. Do najważniejszych wydarzeń 2014 r. można zaliczyć przedstawienie raportu z prac rządu przez premiera Chin Li Keqianga podczas otwarcia drugiej sesji XII Ogólnochińskiego Zgromadzenia Przedstawicieli Ludowych, w którym apelował o dalszą intensyfikacje prac nad planowaniem oraz budową Pasa i Szlaku ${ }^{4}$. Ponadto w tym samym roku wydane zostało wspólne oświadczenie w sprawie pogłębienia wszechstronnego strategicznego partnerstwa UE - Chiny, w ramach którego mają zostać podjęte kroki w kierunku stworzenia synergii pomiędzy inicjatywą i unijnymi regulacjami, jak również w kierunku wykorzystania możliwości współpracy w ramach Pasa i Szlaku5 ${ }^{5}$ Co więcej, ogłoszono ustanowienie dwóch instytucji finansowych kluczowych dla rozwoju Pasa i Szlaku, a mianowicie Azjatyckiego Banku Inwestycji Infrastrukturalnych (AIIB) oraz Funduszu Jedwabnego Szlaku'

Na początku 2015 r. Narodowa Komisja Rozwoju i Reform wydała dokument zatytułowany Wizja i działania w sprawie wspólnego budowania pasa gospodarczego wzdłuż Jedwabnego Szlaku i Morskiego Jedwabnego Szlaku XXI wieku (dalej: Wizja i działania) (Vision and Actions on Jointly Building Silk. Road Economic Belt and $21^{1 t}$ Century Maritime Silke Road), który może być uznany za bardzo ważny krok w kierunku zde-

3 J. Konings, Trade Impacts of the Belt and Road Initiative, Internationale Nederlanden Groep, 2018, s. 1, https://think.ing.com (dostęp: 15.04.2018).

4 Keqiang Li, Report on the Work of the Government 2014, The State Council of The People's Republic of China, 2014, s. 1-2, http://english.gov.cn/archive/publications/2014/08/23/content_281474982987826.htm (dostęp: 15.04.2018).

5 Yucai Qin, Guping Zhou, Weidong Luo, Interpreting the Belt and Road Initiative, Zhejiang University Press, Hangzhou 2017, s. 48.

6 Xinhua, Chronology of China's Belt and Road Initiative, The State Council of the People's Republic of China, 2015, s. 1-2. http://english.gov.cn/news/top_news/2015/04/20/content_281475092566326.htm (dostęp: 15.04.2018). 
finiowania strategii z uwagi na fakt, że określił on m.in. jej założenia, priorytety oraz strukturę, jak również ramy geograficzne ${ }^{7}$. Niemniej, pomimo zarysowania granic na mapie dokument ten wyraźnie wskazuje, że Pas i Szlak to otwarta inicjatywa, do której może przyłączyć się każdy kraj oraz region, bez względu na to, czy znajduje się wzdłuż pierwotnego szlaku. Jeśli chodzi o Chiny, w 2017 r. 19 prowincji, regionów autonomicznych oraz miast pełniło funkcję kluczowych centrów wzdłuż Pasa i Szlaku. Ponadto 15 chińskich portów przystapiło do realizacji strategicznego projektu, w tym Szanghaj, Tianjin, Kanton, Shenzhen oraz wiele innych ${ }^{8}$.

W 2016 r. został ogłoszony kolejny wymiar Pasa i Szlaku, a mianowicie Informacyjny Jedwabny Szlak. Może on być rozumiany jako projekt dążący do stworzenia platformy dla wielostronnej wymiany danych i informacji, jak również do poprawy komunikacji pomiędzy krajami członkowskimi ${ }^{9}$ Informacyjny Jedwabny Szlak promuje również ułatwianie handlu międzynarodowego poprzez zaawansowane technologie. Niedługo po ogłoszeniu tej odnogi projektu poszerzył on swój zakres i poprzez połączenie z gospodarką cyfrową wyewoluował do Cyfrowego Jedwabnego Szlaku, który nie tylko skupia się na wymianie informacji i ułatwianiu komunikacji, ale również na promowaniu innowacji i rozwoju w takich dziedzinach, jak sztuczna inteligencja czy handel elektroniczny.

Wraz z wchodzeniem w nową fazę rozwoju 4 pierwsze lata inicjatywy zostały podsumowane przez przewodniczącego Xi w przemówieniu podczas ceremonii otwarcia Forum Pasa i Szlaku (Belt and Road Forum for International Cooperation) w 2017 r. Od ogłoszenia strategicznej wizji ponad 100 krajów i międzynarodowych organizacji dołączyło do inicjatywy, 40 z nich podpisało z Chinami porozumienia o współpracy. Ponadto rozpoczęto liczne międzynarodowe projekty infrastrukturalne, m.in. szybką kolej Dżakarta-Bagdad, połączenie kolejowe Chiny-Laos, połączenie kolejowe Węgry-Serbia czy też bezpośrednie połączenie z Chengdu do Łodzi. Łącznie projekty te objęły niemalże 70 krajów w Azji, Afryce, Środkowym Wschodzie, Europie oraz Oceanii ${ }^{10}$. Jeżeli chodzi o kwestię handlu, w latach 20142016 łączna wartość handlu pomiędzy Chinami a krajami Pasa i Szlaku przekroczyła 3 bln USD. Chińskie inwestycje w tych krajach wyniosły ponad 50 mld USD ${ }^{11}$.

7 National Development and Reform Commission, Vision and Actions on Jointly Building Silk. Road Economic Belt and 21t Century Maritime Silk Road, Beijing 2015, s. 1-11.

8 D. Naisbitt, J. Naisbitt, L. Brahm, Creating Megatrends: The Belt and Road, China Industry \& Commerce Associated Press Co., Ltd., Beijing 2017, s. 42-45.

9 Xu Wei, Mao Weihua, Information Silk Road Given Lift, „China Daily”, 20.09.2016, http:// english.gov.cn/news/international_exchanges/2016/09/20/content_281475446482788.htm (dostęp: 13.07.2018).

10 S. Deorukhkar, Le Xia, China: One Belt..., s. 1.

11 Treść przemówienia przewodniczącego Xi Jinpinga podczas Belt and Road Forum for International Cooperation, Xinhua, 2017, s. 3, http://www.xinhuanet.com//english/2017-05/14/ c_136282982.htm (dostęp: 15.04.2018). 
Pomiędzy 2005 i 2016 r. inwestycje dotyczyły w szczególności takich obszarów, jak: energia (50\%), transport (18\%), konstrukcja nieruchomości (11\%), górnictwo (8\%) oraz rolnictwo (3\%). Pomiędzy rokiem 2013 i 2015 Chiny inwestowały głównie w Singapurze oraz innych rozwijających się miejscach w Azji, jak Indonezja, Laos czy Tajlandia ${ }^{12}$. W 2016 r. AIIB zatwierdził osiem projektów w krajach Pasa i Szlaku, m.in. w Tadżykistanie, Pakistanie czy Indonezji, gwarantując pożyczkę w wysokości blisko 3 mld USD ${ }^{13}$.

Faza 2: planowanie (2016-2021). Rok 2017 jest często określany jako okres, w którym inicjatywa Pasa i Szlaku nabrała tempa. Zgodnie z oficjalnym portalem internetowym projektu do lipca 2018 r. do inicjatywy dołączyło 80 krajów, wliczając Chiny. Wiele z nich zaangażowało się w $2017 \mathrm{r} \cdot{ }^{14}$ Poza oficjalnymi państwami członkowskimi 14 krajów niebędących członkami inicjatywy uczestniczyło w Forum Pasa i Szlaku ${ }^{15}$. W pierwszych 11 miesiącach 2017 r. wymiana handlowa pomiędzy Chinami i krajami członkowskimi wyniosła 983 mld USD, wykazując wzrost o 15,4\% w stosunku do roku poprzedniego ${ }^{16}$. Liczba członków AIIB wzrosła do 87. Bank zatwierdził 28 projektów, podczas gdy łączna wartość inwestycji przekroczyła $5 \mathrm{mld}$ USD $^{17}$. Do listopada 2017 r. podpisano 16 porozumień o wolnym handlu ${ }^{18}$.

W tym samym roku Narodowa Komisja Rozwoju i Reform wydała dokument Wizja w sprawie morskiej współpracy w ramach Pasa i Szlaku (Vision for Maritime Cooperation under the Belt and Road). Określono w nim plan majacy na celu ustanowienie tzw. Niebieskiej Współpracy (Blue Partnership), w ramach której dąży się m.in. do budowy trzech morskich „niebieskich przejść ekonomicznych” (blue economic passages $)^{19}$.

Z perspektywy Chin inicjatywa Pasa i Szlaku ma ogromne znaczenie. Pozwala na wprowadzenie kraju w kolejny etap strategii otwierania się na świat. Poprzez wielostronną współpracę Chiny będą w stanie osiagnąć stabilniejszy i bardziej

12 S. Deorukhkar, Le Xia, China: One Belt..., s. 4-5.

13 Approved Projects. Asian Infrastructure Investment Bank, https://www.aiib.org/en/projects/approved/index.html (dostęp: 13.07.2018).

14 International Cooperation. Belt and Road Portal, https://eng.yidaiyilu.gov.cn/info/iList. jsp?cat_id=10076 (dostęp: 31.07.2018).

15 K. Coppel, New Frontiers: Prospects for Real Estate Along the Belt and Road Initiative, Knight Frank Research, Singapore 2018, s. 35.

16 Liu Yue, Yearender: Belt and Road gains momentum in 2017, Belt and Road Portal, 2018, s. 1, https://eng.yidaiyilu.gov.cn/home/rolling/44265.htm (dostęp: 15.04.2018).

17 Asian Infrastructure Investment Bank, https://www.aiib.org/en/index.html (dostęp: 13.07.2018).

18 Liu Yue, Yearender: Belt and Road..., s. 6.

19 National Development and Reform Commission, and State Ocean Administration, Vision for Maritime Cooperation under the Belt and Road, 2017, s. 1-4, https://www.yidaiyilu.gov.cn/wcm. files/.../201706200153032.pdf (dostęp: 13.07.2018). 
zrównoważony rozwój, jak również stworzyć nowe elementy przewagi konkurencyjnej na arenie międzynarodowej, głównie dzięki wzmacnianiu postępu przemysłowego, ale też dzięki tworzeniu korzystniejszych warunków handlowych. Przed wprowadzeniem inicjatywy Pasa i Szlaku Chiny były do pewnego stopnia ograniczone przez lokalne warunki i surowce. Sytuacja ta diametralnie zmieniała się wraz z rozwojem strategicznej wizji i nawiązywaniem coraz to nowych relacji ze światem w ramach Jedwabnego Szlaku ${ }^{20}$. Zgodnie z danymi łączna wartość nowych zleceń infrastrukturalnych przekazanych Chinom w 2016 r. przez kraje członkowskie wyniosła 126 mld USD, co stanowi 52\% wszystkich chińskich globalnych projektów w zakresie inżynierii, dostawy maszyn i budowy ${ }^{21}$. Jeśli chodzi o handel, liczne porozumienia o wolnym handlu przyczyniły się do poprawy warunków wymiany dóbr pomiędzy Chinami i poszczególnymi krajami. Do listopada 2017 r. dokumenty o współpracy zostały podpisane z 74 krajami uczestniczącymi w inicjatywie, w tym 24\% stanowiły porozumienia o współpracy handlowej lub gospodarczej ${ }^{22}$. Z uwagi na rolę, jaką strategiczna wizja Pasa i Szlaku odgrywa w rozwoju Chińskiej Republiki Ludowej, w październiku 2017 r. została ona włączona do Konstytucji Komunistycznej Partii Chin.

W przyszłości można oczekiwać, że więcej dwustronnych i wielostronnych projektów będzie realizowanych w ramach Pasa i Szlaku. Biorąc pod uwagę aktualne trendy, można spodziewać się dalszego zacieśniania relacji z krajami położonymi w Afryce oraz Ameryce Południowej. Szacuje się, że pomiędzy 2016 i 2030 r. projekty prowadzone w krajach Pasa i Szlaku będą wymagały inwestycji o łącznej wysokości ponad 22 bln USD, co w przeliczeniu daje 1,5 bln USD rocznie. Głównie mowa o inwestycjach w infrastrukturę energetyczna, transportową oraz telekomunikacyjną 23 .

Ekspansja gospodarcza Chin wiąże się również z wieloma zagrożeniami dla aktualnego ameryko-centrycznego porządku. Jedną z głównych obaw Stanów Zjednoczonych jest globalizacja chińskiego juana, która może doprowadzić do zachwiania niemalże monopolistycznej pozycji dolara na rynku światowym. Ponadto brak zaufania wzbudza również model gospodarczy Chin, który bardzo różni się od modelu zachodniego opierającego się na wolnym rynku. Chiński naukowiec Qiu Xiaohua w przemówieniu podczas XIII Forum CDPEC w Xi’an, które odbyło się pod koniec listopada 2018 r., spekulował, że powyższe czynniki, jak również strach przed rosnąca pozycją nowego gracza na rynku międzynarodowym, jakim są Chiny, doprowadziły do sino-amerykańskiej wojny handlowej.

20 Yucai Qin, Guping Zhou, Weidong Luo, Interpreting the Belt..., s. 206-207.

21 S. Deorukhkar, Le Xia, China: One Belt..., s. 2.

22 Evolution of the B\&R Friends Circle: Upgrading of Cooperation, Belt and Road Portal, 2017, https://eng.yidaiyilu.gov.cn/jcsj/dsjkydyl/34593.htm (dostęp: 13.07.2018).

23 S. Deorukhkar, Le Xia, China: One Belt..., s. 4. 
Cyfrowy Jedwabny Szlak jest jednym z najnowszych wymiarów inicjatywy Pasa i Szlaku, stanowiącym pewnego rodzaju uzupełnienie do szlaków lądowych, morskich i powietrznych. Sama koncepcja została po raz pierwszy zaprezentowana na arenie międzynarodowej w 2015 r. w Brukseli podczas posiedzenia Okragłego Stołu UE-Chiny, dotyczącego cyfrowej współpracy. Może być on rozumiany jako wynik połączenia gospodarki cyfrowej i chińskiej inicjatywy Jedwabnego Szlaku. Aby móc w pełni zrozumieć Cyfrowy Jedwabny Szlak, niezbędne jest poznanie obu jego składowych.

Gospodarka cyfrowa (digital economy) to zjawisko opisane po raz pierwszy przez Dona Tapscotta w 1995 r., odnoszące się do nowej ekonomii, która rozwijała się pod wpływem cyfrowych technologii, m.in. sieci internetowej, internetu przedmiotów (Internet of things - IoT), robotyki, big data (obszerne dane) oraz analityki, sztucznej inteligencji czy też uczenia się maszyn. W przeglądzie Inicjatywy G20 na rzecz Współpracy i Rozwoju Gospodarki Cyfrowej nowa ekonomia została zdefiniowana jako: „szeroki zakres działalności gospodarczej, która zakłada wykorzystanie informacji oraz wiedzy w formacie cyfrowym jako kluczowego czynnika produkcji, nowoczesnych sieci informacyjnych jako ważnych obszarów działalności, jak również efektywne wykorzystanie technologii informacyjno-komunikacyjnej (TIK) jako ważnego czynnika wzrostu produktywności oraz optymalizacji strukturalnej ekonomii. Internet, cloud computing (przetwarzanie w chmurze), big data i internet przedmiotów, fintech oraz inne technologie cyfrowe są wykorzystywane do zbierania, przechowywania, analizowania oraz udostępniania informacji cyfrowo, jak również przekształcania interakcji społecznych"24.

W ksiazice The Digital Economy - Promise and Peril in the Age of Networked Intelligence Tapscott porównuje „starą i nową” ekonomię w następujący sposób: stara ekonomia charakteryzuje się fizycznym przepływem informacji, w tym m.in. wymiana pieniędzy lub faktur twarzą w twarz, natomiast w nowej ekonomii następuje cyfrowa wymiana informacji, które zostały zredukowane do bitów danych możliwych do przesłania z prędkością światła pomiędzy komputerami. Ponadto nowa ekonomia jest zaprezentowana jako ekonomia wiedzy, w której know-how tworzy wartość dodaną produktu. Wiedza jest kluczowa w gospodarce cyfrowej do tego stopnia, że produkty będące w obiegu same w sobie zawierają treść i mogą między sobą reagować, jak np. inteligentne samochody z Bluetooth, inteligentne domy czy popularne smartfony. Dzięki analizie danych wiedza, pomysły i preferencje klientów stają się częścią produktu końcowego ${ }^{25}$. Ponadto personalizacja produktów i usług odgrywa znaczącą rolę w walce o klienta. Jest to wyjątkowo ważne w dzisiejszych czasach

${ }^{24}$ G20 Digital Economy Development and Cooperation Initiative (I. Overview: Global Economy in a Digitized World). G20 Hangzhou Summit, 2016, s. 1, http:/www.g20.utoronto. ca/2016/g20-digital-economy-development-and-cooperation.pdf (dostęp: 26.05.2018) (tłum. M. Majcherczyk).

25 D. Tapscott, The Digital Economy - Promise and Peril in the Age of Networked Intelligence, McGraw-Hill 1995, s. 34-35. 
w cyfrowym marketingu, w szczególności w Chinach, gdzie 31\% konsumentów jest skłonnych do kliknięcia na reklamę, która jest w jakiś sposób z nimi związana, podczas gdy w skali globalnej proporcja ta wynosi jedynie $16^{\%} 0^{26}$. Niemniej wiedza nie jest jedynym kluczowym aspektem gospodarki cyfrowej. Tapscott przywołuje 12 charakterystyk nowej ekonomii, a jedna z nich jest wiedza. Pozostałe to m.in. cyfryzacja, wirtualizacja, innowacja i globalizacja.

Gospodarka cyfrowa i rozwój technologii wpłynęły nie tylko na produkty, ale również na proces transformacji przemysłu. Z uwagi na niewattpliwie istotne osiagnięcia lata 60. XX wieku są określane jako trzecia rewolucja przemysłowa, skupiona na technologii informacyjno-komunikacyjnej. Do ważniejszych innowacji tych czasów można zaliczyć komputer osobisty PC, e-mail, e-commerce czy telefonię komórkową. W niedalekiej przeszłości trzecia rewolucja przemysłowa weszła w okres cyfryzacji, który jest znany również jako „druga era maszynowa”. Pojawienie się zaawansowanych technologii cyfrowych w dużym stopniu wpłynęło na produkcję, sprzedaż detaliczną lub hurtową, jak również logistykę. Wszystkie te procesy stają się coraz bardziej zautomatyzowane i zcyfryzowane, aby móc sprostać rosnącym wymaganiom nowego typu klienta, który przyzwyczaja się do wygody, jaką niesie z sobą postęp technologiczny. Firmy wykorzystują komputery oraz roboty do podniesienia produktywności, technologię uczenia się maszyn do zarządzania magazynami i strategią e-handlu oraz media społecznościowe do zrozumienia potrzeb klienta ${ }^{27}$. Biznesy logistyczne dążą do zwiększenia efektywności wraz z redukcją kosztów poprzez budowę coraz to bardziej zautomatyzowanych magazynów, jak chiński gigant e-handlu Alibaba. Niektóre przedsiębiorstwa idą o krok dalej, jak np. Amazon pracujący nad dronami dostawczymi i pojazdami poruszającymi się bez udziału kierowcy.

Podsumowując, Cyfrowy Jedwabny Szlak jest projektem realizowanym pod przewodnictwem Chin, który zmierza do poprawienia połączeń pomiędzy państwami członkowskimi, m.in. w celu usprawnienia wymiany danych, informacji, technologii oraz wiedzy, jak również promowania i ułatwienia globalnego handlu elektronicznego oraz międzynarodowej wymiany kulturalnej i ideologicznej poprzez prowadzenie dwustronnych oraz wielostronnych projektów. Pierwsze kroki w kierunku rozwinięcia Cyfrowego Jedwabnego Szlaku zostały wspomniane w dokumencie Wizja i działania. Pojawiły się tam m.in. informacje na temat stworzenia sieci kabli światłowodowych czy poprawy jakości przepływu danych przestrzennych w celu poszerzenia zakresu wymiany informacji ${ }^{28}$.

26 eCommerce in China - the Future is Already Here, PricewaterhouseCoopers, 2017, s. 10, https:// www.pwccn.com/en/retail-and-consumer/publications/total-retail-2017-china/total-retail-survey-2017-china-cut.pdf (dostęp: 15.05.2018).

${ }^{27}$ C. D'Souza, D. Williams, The Digital Economy, Canadian Economic Analysis Department, „Bank of Canada Review”, Spring 2017, s. 1-2, https://www.bankofcanada.ca/wp-content/ uploads/2017/05/boc-review-spring17-dsouza.pdf (dostęp: 14.07.2018).

28 Vision and Actions..., s. 5. 
Warto zaznaczyć, że w lipcu 2018 r. został ukończony etap jednego z ważniejszych projektów w ramach Cyfrowego Jedwabnego Szlaku, a mianowicie budowy transgranicznych kabli światłowodowych, który stanowi część Korytarza Ekonomicznego Chiny - Pakistan. Łączna długość kabla łączącego Chiny i Pakistan, który jest również nazywany pierwszą cyfrową autostradą Chiny - Pakistan, wynosi $820 \mathrm{~km}$, a koszt projektu przekroczył $40 \mathrm{mln}$ USD. Co godne uwagi, w ramach tego przedsięwzięcia stworzono najwyżej położoną na świecie sieć kabli światłowodowych, ponieważ łączy ona Rawalpindi z Khunjerab na wysokości 4700 m n.p.m. Szacuje się, że całkowita długość kabli w kolejnych etapach projektu może osiągnąć $2950 \mathrm{~km}^{29}$.

Istnieją również inne podobne projekty $\mathrm{w}$ ramach Cyfrowego Jedwabnego Szlaku, które mają na celu wspólną konstrukcję sieci kabli światłowodowych, m.in. Pakistan-East Africa Cable Express (PEACE), który od 2017 r. jest koordynowany przez chińską firmę Huawei. Według planów sieć PEACE ma w pierwszej kolejności połączyć Pakistan i Kenię przez Djibouti. Następnie ma zostać rozgałęziona na północ aż do Egiptu i na południe do Afryki Południowej. Łączna długość całego korytarza cyfrowego może osiagnąć nawet 13 tys. $\mathrm{km}^{30}$. Ponadto Chiny są również zaangażowane w rozwijanie sieci $5 \mathrm{G}$, które mają za zadanie polepszenie prędkości połączeń międzynarodowych oraz ułatwienie przesyłania danych. Jedna z możliwych dróg wykorzystania big data w Cyfrowym Jedwabnym Szlaku została zaprezentowana przez profesora Chińskiej Akademii Nauk Guo Huadonga. Jego zdaniem istnieje szansa na poprawę reakcji krajów afrykańskich na zmiany klimatu oraz klęski żywiołowe, takie jak susze, m.in. za pomocą zaawansowanej analizy danych ${ }^{31}$.

Choć Cyfrowy Jedwabny Szlak jest nowym projektem, to rozwija się w relatywnie szybkim tempie, co może wynikać z faktu, że doskonale wpasowuje się w trend globalnego rozwoju, w szczególności w dążenie do promowania gospodarki cyfrowej. Liczne organizacje potwierdziły niezwykle ważną rolę rozwoju cyfrowego $i$ technologicznego. Dołączenie do projektu Cyfrowego Jedwabnego Szlaku jest jedną z dróg promowania wyżej wspomnianego postępu. Wśród przewag konkurencyjnych projektu można wskazać tzw. efekt sieci, zarówno bezpośredni, jak i pośredni. Pierwszy odnosi się do sytuacji, w której wartość cyfrowego produktu lub usług rośnie wraz ze wzrostem liczby użytkowników. Innymi słowy, bezpośredni efekt

29 Breakthrough! The First Direct Fiber Optic Cable Was Built, Belt and Road Portal We-chat Official Account, 2018, https://baijiahao.baidu.com/s?id=1606469482855418575\&wfr=spider\& for $=p c$ (dostęp: 20.07.2018).

30 The Economist Intelligence Unit, China's Digital Silk Road, https://www.business.hsbc.com/ belt-and-road/chinas-digital-silk-road (dostęp: 16.07.2018).

31 Xinhua, Digital Silk Road on Path to Sustainable Development, The State Council Information Office of the People's Republic of China, 2017, http://english.scio.gov.cn/beltandroad/2017-09/05/ content_41533957.htm (dostęp: 16.07.2018). 
sieci następuje wówczas, gdy użytkownicy czerpią korzyść z łączenia się z innymi użytkownikami tej samej sieci. Pośredni efekt sieci odnosi się do sytuacji, w której wartość sieci rośnie wraz z jej zawartością, to znaczy, że im większa zawartość, tym atrakcyjniejsza sieć ch $^{2}$.

Facebook, Instagram czy Twitter mogą być przykładami występowania bezpośredniego efektu sieci. Wartość tych portali jest niezaprzeczalnie powiązana z liczbą użytkowników. Tę samą zasadę można by zastosować w przypadku Cyfrowego Jedwabnego Szlaku. Fakt, że projekt Pasa i Szlaku zgromadził w swoich ramach kraje Azji, Europy, Ameryki Południowej oraz Oceanii, może przyczyniać się do wzrostu wartości cyfrowego wymiaru inicjatywy. Nie byłoby mowy o prawdziwym globalnym wpływie usprawnienia i ułatwienia połączeń pomiędzy krajami, gdyby społeczność była zbyt mała, tak więc być może atrakcyjność Pasa i Szlaku jest bezpośrednio związana z liczbą uczestników inicjatywy. Im większa społeczność, tym bardziej korzystne wydaje się dołączenie do niej, szczególnie biorąc pod uwagę możliwość nawiązania nie tylko dwustronnych relacji z Chinami, ale również wielostronnej współpracy z innymi krajami członkowskimi. W rezultacie, jeśli projekt osiagnie sukces, Cyfrowy Jedwabny Szlak może przyczynić się do stworzenia globalnej sieci kabli światłowodowych oraz do połączenia świata w cyfrowym wymiarze poprzez handel międzynarodowy czy współpracę w zakresie wymiany danych satelitarnych.

Portale, takie jak Booking czy nawet platformy e-commerce, jak Amazon czy Alibaba, moga być przykładami biznesów, których wartość zależy od zawartości. Strona booking.com nie byłaby przydatna, gdyby nie oferowała szerokiej gamy hoteli nawet $\mathrm{w}$ małych miasteczkach na całym świecie. Amazon nie osiagnąłby sukcesu, gdyby nie fakt, że już na samym początku działalności w 1995 r. oferował ponad $1,5 \mathrm{mln}$ pozycji ${ }^{33}$. Analogicznie można by powiedzieć, że wartość Cyfrowego Jedwabnego Szlaku jest związana z jego zawartością, którą można interpretować jako zakres projektów w ramach inicjatywy. Jest on na tyle obszerny, że bez względu na fakt, czy dany kraj potrzebuje kabli światłowodowych, dwustronnych memorandów porozumienia odnośnie do globalnego handlu elektronicznego czy sieci 5G, praktycznie zawsze będzie istniała możliwość zrealizowania nowego projektu, który będzie mógł przynieść zadowalające efekty.

Cyfrowa ekspansja Chin może wzbudzać kontrowersje, szczególnie biorąc pod uwagę wydarzenia ostatnich lat, w których centrum znalazło się dwóch chińskich producentów telefonów komórkowych, a mianowicie ZTE oraz Huawei. Z uwagi na podejrzenia o pozyskiwanie danych osobowych oraz możliwe inne nielegalne kroki Stany Zjednoczone skutecznie utrudniają obu firmom sprzedaż produktów

\footnotetext{
32 N. Collin, A. Landier, P. Mohnen, A. Perrot, The Digital Economy, „French Council of Economic Analysis" 2015, vol. 7, no. 26, s. 1-12.

33 R.L. Brandt, One Click, Jeff Bezos and the Rise of Amazon.com, London 2012, s. 67-71.
} 
do tego stopnia, że na początku 2018 r. agencja wywiadu USA wydała oświadczenie ostrzegające obywateli przed zakupem telefonów komórkowych ZTE lub Huawei ${ }^{34}$.

\section{Cross-border e-commerce wzdłuż Cyfrowego Jedwabnego Szlaku}

Cyfrowy Jedwabny Szlak jest jednym z wymiarów Pasa i Szlaku, stanowi więc część projektu rewitalizacji starożytnego Jedwabnego Szlaku. Pierwotnie drogi łączące Chiny ze światem służyły wielorakim celom, jednym z nich był handel. Wymiana dóbr stanowiła filar starożytnych szlaków i odgrywa równie ważną rolę współcześnie. Sama struktura nowego Jedwabnego Szlaku nie uległa wielkim zmianom w porównaniu do jego poprzednika. Niemniej metoda przeprowadzenia transakcji handlowej przeszła transformację, m.in. dzięki cyfryzacji gospodarki. Trudno nie dostrzec roli Internetu w całym procesie. Można powiedzieć, że jest on uniwersalną i najpopularniejsza platformą używaną do interakcji pomiędzy użytkownikami. Od końca XX wieku stał się nieograniczoną przestrzenią dla transakcji handlowych i globalny e-handel jest jednym z jej wymiarów.

Koncept Cyfrowego Jedwabnego Szlaku pojawił się dekady później niż międzynarodowy handel elektroniczny, tak więc nie jest poprawne stwierdzenie, że globalny e-handel stanowi chińską inicjatywę. Niemniej można powiedzieć, że oba elementy tworzą niejako harmonijny system. Globalny e-handel jest również jedną z metod rozwijania zarówno terytorialnego, jak i Cyfrowego Jedwabnego Szlaku, przy czym należy podkreślić, że oba mogą istnieć niezależnie.

Istnieje obustronnie korzystna relacja pomiędzy Cyfrowym Jedwabnym Szlakiem i globalnym e-handlem. Ponadto oba elementy są również siłami napędowymi wzajemnego wzrostu, a kluczowym aspektem w tym systemie jest rozwój infrastruktury. Podobna sytuacja ma miejsce w przypadku Pasa i Szlaku oraz tradycyjnego handlu. Jak można już było zauważyć, Chiny są głównie zaangażowane w budowę infrastruktury w krajach członkowskich oraz pomiędzy nimi, co może m.in. przyczynić się do ułatwienia przepływu dóbr. Równocześnie zwiększenie obrotów handlowych pozytywnie wpływa na rozwój inicjatywy. Analogicznie konstrukcja zaawansowanej infrastruktury dla globalnego e-handlu ułatwi budowę stabilniejszych relacji w ramach gospodarki cyfrowej, które to mogą prowadzić do dalszego rozwoju Cyfrowego Jedwabnego Szlaku. Infrastruktura transgranicznego handlu elektronicznego odnosi się zarówno do środowiska on-line, jak i off-line. Z jednej strony mowa o międzynarodowym systemie płatności mobilnych, a z drugiej o rozbudowanej sie-

34 S. Larson, The FBI, CIA and NSA Say American Citizens Shouldn't Use Huawei Phones, https:// money.cnn.com/2018/02/14/technology/huawei-intelligence-chiefs/index.html?iid=EL (dostęp: 30.11.2018). 
ci logistycznej. Inicjatywa Pasa i Szlaku jako fizyczne wsparcie cyfrowego projektu dąży do poprawy warunków handlu pomiędzy krajami członkowskimi, co wpływa na rozwój globalnego e-handlu. Im więcej lądowych, morskich oraz powietrznych połączeń, umów o wolnym handlu czy stref wolnego handlu, tym bardziej efektywny międzynarodowy handel elektroniczny i związany z nim proces logistyki. Im efektywniejszy proces globalnego e-handlu, tym więcej krajów i przedsiębiorstw będzie chętnych do zaangażowania się.

Usprawnienie procesu transgranicznego handlu elektronicznego może również zostać osiągnięte poprzez e-odprawę celną, możliwość weryfikacji dokumentów on-line, wystawienie elektronicznych dokumentów handlowych, w tym faktur czy listów przewozowych, ułatwienie płatności elektronicznych i on-line w zagranicznych walutach. Jednym z rozwiązań mogących przyczynić się do stabilnego rozwoju globalnego e-handlu jest wspomniana w Wizji i działaniach transparentność handlu międzynarodowego oraz redukcja kosztów odprawy celnej ${ }^{35}$.

Przewodniczacy Xi odniósł się również do problemu rozwoju Cyfrowego Jedwabnego Szlaku i globalnego handlu elektronicznego podczas ceremonii otwarcia Forum Pasa i Szlaku, podkreślając ważną rolę, jaką odgrywają nauka, technologia i innowacja oraz promowanie współpracy międzynarodowej w e-handlu dla przyszłości inicjatywy. Wspomniany rozwój innowacyjny ma skupiać się m.in. na sztucznej inteligencji, cloud computing oraz innych dziedzinach gospodarki cyfrowej, mając na celu transformację miast w Cyfrowy Jedwabny Szlak XXI wieku' ${ }^{36}$.

Poza rozbudową infrastruktury Cyfrowy Jedwabny Szlak może również zagwarantować e-biznesom lepszy dostęp do rynku międzynarodowego. Dane wykazuja, że łączna liczba ludności krajów wzdłuż Pasa i Szlaku osiagnę̧ła około 4,4 mld, stanowiąc ponad $60 \%$ populacji świata. Nie da się ukryć, że jest to atrakcyjna liczba potencjalnych konsumentów. Do stycznia 2018 r. wzdłuż Jedwabnego Szlaku położonych było 18 miast o liczbie ludności powyżej $10 \mathrm{mln}$, w tym Pekin, Moskwa czy Istambuł ${ }^{37}$. Równie znaczący jest fakt, że w latach 2014-2016 wartość handlu pomiędzy Chinami a krajami Pasa i Szlaku przekroczyła 3 bln USD ${ }^{38}$. Biorąc pod uwagę rozwój relacji handlowych pomiędzy krajami członkowskimi inicjatywy, można spodziewać się, że wartość ta wzrośnie.

Istnieje oczywiście wiele wyzwań dla e-biznesów, m.in. różnice kulturowe, komunikacja w języku obcym, zawiły proces logistyczny czy płatność w obcej walucie.

35 Vision and Actions..., s. 5.

36 Treść przemówienia przewodniczącego Xi Jinpinga podczas Belt and Road Forum for International Cooperation, s. 3.

37 Huadong Guo, Steps to the Digital Silk Road, „Nature. International Journal of Science” 2018, no. 554, s. 25-27, https://www.nature.com/articles/d41586-018-01303-y (dostęp: 15.04.2018).

38 China's Center for Information Industry Development, Digital Silk Road: The Opportunities and Challenges to Develop Digital Economy along the Belt and Road, Posts \& Telecom Press, Beijing 2017 (12), s. 194. 
Można uznać, że inicjatywa Pasa i Szlaku będzie w stanie pozytywnie wpłynąć na rozwiązanie wyżej wspomnianych problemów poprzez międzynarodowe umowy i porozumienia. Niemniej na rzeczywiste rezultaty trzeba będzie jeszcze poczekać, ponieważ jest to relatywnie nowy, ciągle rozwijający się projekt.

\section{Alibaba Group}

Alibaba Group została założona w 1999 r. przez Jacka Ma i w ciagu niespełna 20 lat stała się gigantem światowego handlu elektronicznego. Początkowo firma oferowała jedynie usługi łączenia chińskich producentów z firmami z całego świata poprzez portal Alibaba.com. Popularność platformy przerosła wszelkie oczekiwania - do 2001 r. zgromadziła ponad milion zarejestrowanych użytkowników ${ }^{39}$. Dwa lata później założony został najbardziej popularny portal firmy, a mianowicie Taobao - internetowa platforma handlu C2C. W lutym 2005 r. Taobao zebrało ponad $5 \mathrm{mln}$ produktów i 4,5 mln użytkowników ${ }^{40}$. Po jedynie 2 latach od założenia platforma mogła pochwalić się aż $48 \mathrm{mln}$ zarejestrowanych użytkowników w Chinach, których liczba wzrastała w zawrotnym tempie 80 tys. osób dziennie. Dane wskazują, że dzienna średnia wartość transakcji przekraczała $150 \mathrm{mln} \mathrm{CNY}^{41}$. Globalna ekspansja firmy rozpoczęła się w 2007 r. wraz z utworzeniem pierwszego zagranicznego biura Alibaba.com w Genewie. Rok później Taobao zostało uzupełnione o T-mall oraz T-mall Global, platformy e-handlu oferujące wyłącznie zagraniczne marki ${ }^{42}$. W 2015 r. na T-mall Global można było zakupić produkty z ponad 11 krajów, takich jak USA, Australia, Nowa Zelandia czy Hiszpania.

Szybki rozwój firmy sprawił, że duży nacisk położono na budowę efektywnego systemu logistycznego, bez którego dalsza ekspansja byłaby praktycznie niemożliwa. W 2011 r. ogłoszono, że Alibaba Group planuje zainwestować co najmniej 1,5 mld USD w rozwój nowoczesnej infrastruktury logistycznej. Szacowana łączna powierzchnia magazynowa ma wynieść $3 \mathrm{mln} \mathrm{m}^{2(43)}$. Szczególnie ważnym aspektem rozwoju Alibaba Group jest projekt Rural Taobao, który skupia się na budowie tysiąca centrów operacyjnych na poziomie gminnym oraz 100 tys. wiejskich centrów, których zadaniem

${ }^{39}$ History and Milestones. Alibaba Group, https://www.alibabagroup.com/en/about/history?year=2001 (dostęp: 18.07.2018).

40 Alibaba.com Launches Online Payment Solution in China, https://www.alibabagroup.com/en/ news/press_pdf/p050202.pdf (dostęp: 18.07.2018).

${ }^{41}$ Alipay Goes Global, https://www.alibabagroup.com/en/news/press_pdf/p070828.pdf (dostęp: 18.07.2018).

42 Taobao Mall Launches New Independent Web Domain, Shares Strategy to Elevate Online Shopping Infrastructure, https://www.alibabagroup.com/en/news/press_pdf/p101101.pdf (dostęp: 18.07.2018).

43 Alizila Staff, Alibaba Group Calls for Logistics Revolution, Alizila, 19.01.2011, https://www.alizila.com/alibaba-group-calls-for-logistics-revolution/ (dostęp: 18.07.2018). 
jest usprawnienie transportu przesyłek do terenów oddalonych od dużych miast oraz promowanie konsumpcji. Warto wspomnieć, że w 2014 r. liczba e-transakcji w obszarach wiejskich była o $24,1 \%$ niższa niż w miastach ${ }^{44}$. W celu efektywnego rozwijania systemu logistycznego Alibaba Group założyła Cainiao Network we współpracy z największymi chińskimi firmami logistycznymi, takimi jak SF Express czy Yunda. W 2016 r. Cainiao obsługiwało 4,2 mln paczek dziennie, co stanowiło 70\% wszystkich przesyłek nadawanych w Chinach ${ }^{45}$. Aktualnie Alibaba kładzie również nacisk na budowę zautomatyzowanych magazynów i centrów logistycznych w Chinach i za granicą. Dzięki stabilnemu rozwojowi zarówno biznesowemu, jak i logistycznemu Alibaba Group stała się największą firmą w branży e-handlu na świecie.

Rozwój handlu internetowego nie jest jedynym celem założyciela Alibaba Group. W 2016 r., podczas Boao Asia Forum Jack Ma zaproponował założenie Elektronicznej Światowej Platformy Handlowej (eWTP), mającej na celu stworzenie bardziej efektywnych regulacji oraz lepszego otoczenia biznesowego, które pozwoli na stabilny rozwój cross-border e-commerce. W tym samym roku projekt został poparty podczas szczytu G20 w Hangzhou ${ }^{46}$. Ponadto Światowa Organizacja Handlu (WTO) również zaoferowała wsparcie dla rozwoju prywatnej inicjatywy Jacka Ma. Założyciel Alibaba Group dołączył do dyrektora generalnego WTO Roberta Azavedo podczas XI Konferencji Ministerialnej w Davos, gdzie rozpoczęto dyskusję na temat przyszłości handlu elektronicznego. Efektem rozmów była inauguracja projektu „Umożliwić e-Handel", który ma na celu zjednoczenie rządów i biznesów we wspólnym dążeniu do poprawy globalnego środowiska e-handlu ${ }^{47}$. Na początku 2018 r. inicjatywa Jacka Ma została również wsparta przez Rząd Chińskiej Republiki Ludowej podczas I Globalnej Konferencji Cross-Border E-Commerce jako ważny mechanizm pozwalający na prowadzenie prywatno-publicznego dialogu na temat e-handlu. Po zakończeniu konferencji założenia i cele eWTP zostały wpisane do Deklaracji pekińskiej jako pilotażowy projekt wsparcia handlu elektronicznego ${ }^{48}$.

W 2018 r. Jack Ma pozyskał jeszcze jednego ważnego sojusznika, a mianowicie Organizację Narodów Zjednoczonych do spraw Rozwoju Przemysłowego

44 2014-2015 Social Responsibility Report. Alibaba Group, 2015, s. 14-15, http://www.alijijinhui.org/Uploads/file/20160125/56a5b8096e79e.pdf (dostęp: 14.07.2018).

45 Cainiao Network Overview, 2016, s. 3, https://www.alizila.com/wp-content/uploads/2016/09/Cainiao-Factsheet.pdf?x95431 (dostęp: 14.07.2018).

46 European Commission, G20 Leaders' Communique Hangzhou Summit, G20 Hangzhou Summit 2016, s. 6.

47 WTO, World Economic Forum and eWTP launch joint public-private dialogue to open up e-commerce for small business, 11.12.2017, https://www.wto.org/english/news_e/news17_e/ecom_11dec17_e. htm (dostęp: 19.07.2018).

48 Beijing Declaration, First Global Cross-Border E-Commerce Conference, 2018, s. 1, http:// www.wcoomd.org/-/media/wco/public/global/pdf/about-us/legal-instruments/declarations/ beijing-declaration-1022018.pdf?la=en (dostęp: 18.07.2018). 
(UNIDO). UNIDO ogłosiło, że cele zaplanowane w Agendzie na rok 2030, takie jak promowanie stabilnego rozwoju gospodarczego, budowanie infrastruktury czy wspieranie innowacji, mogą zostać osiagnięte poprzez platformę eWTP ${ }^{49}$. Jednym z planów w ramach rozwoju eWTP jest również stworzenie tzw. cyfrowych stref wolnego handlu (digital free-trade zone - DFTZ), które będą ułatwiały finalizację transakcji internetowych na całym świecie. Pierwsza taka strefa została oficjalnie otwarta w Malezji w $2017 \mathrm{r}^{50}$

Alibaba Group jest jednym z najlepszych przykładów firm na Cyfrowym Jedwabnym Szlaku nie tylko ze względu na bardzo dobrze funkcjonujące globalne platformy e-handlu, ale również z uwagi na podjęcie inicjatywy rozwoju eWTP. Elektroniczna Światowa Platforma Handlowa może być rozumiana jako projekt sektora prywatnego w ramach Cyfrowego Jedwabnego Szlaku, który ma na celu stworzenie lepszego i zrównoważonego środowiska biznesowego dla małych i średnich przedsiębiorstw, poprzez zmiany regulacji i rozwój specjalnej infrastruktury on-line i off-line. Co więcej, Jack Ma podkreśla wagę zaawansowanych technologii $\mathrm{i}$ innowacji, które odgrywają również ważną rolę w cyfrowej odnodze projektu Pasa i Szlaku. Można powiedzieć, że z jednej strony Alibaba Group poprzez swoją działalność wspiera rozwój Cyfrowego Jedwabnego Szlaku i realizuje niektóre założenia inicjatywy, z drugiej strony Cyfrowy Jedwabny Szlak może przyczynić się do szybszego rozwoju Alibaba Group oraz projektu eWTP, tak więc istnieje między nimi wzajemnie korzystna relacja.

\section{Podsumowanie}

Cyfrowy Jedwabny Szlak jest jednym z wymiarów Pasa i Szlaku, który powstał w wyniku połączenia chińskiej inicjatywy z gospodarką cyfrowa. Jego relacja z międzynarodowym e-handlem może zostać określona jako dwustronnie korzystna.

Aktualnie, żyjemy w „cyfrowym świecie”, w którym technologia i innowacja stanowią główne siły napędowe rozwoju. Tradycyjny handel międzynarodowy jest stopniowo zastępowany przez globalny e-handel w procesie ekonomicznej selekcji naturalnej. Jednym z głównych powodów tego fenomenu jest najprawdopodobniej wygoda, którą niesie z sobą bazująca na technologii wymiana dóbr. Jedno kliknięcie może prowadzić do finalizacji transakcji pomiędzy firmami lub klientami z różnych części świata.

Jednym z wyzwań globalnego handlu elektronicznego jest konieczność budowy wysoce efektywnej infrastruktury logistycznej. Nie ma wątpliwości co do potrzeby

49 UN General Assembly, Resolution 70/1 Transforming our world: the 2030 Agenda for Sustainable Development, 2015, s. 15.

50 T. Brennan, Ewtp Finds First Overseas Base In Malaysia, Alizila, 22.03.2017, https://www.alizila. com/ewtp-finds-base-malaysia/ (dostęp: 18.07.2018). 
aplikowania inteligentnych rozwiązań przez biznesy, które muszą sprostać coraz to wyższym wymaganiom nowego typu klienta, jaki pojawił się wraz z postępem technologii. Nowy klient oczekuje, że płatność i dostawa będą równie szybkie co zakup za pomoca jednego kliknięcia. W związku z tym promowanie innowacyjności oraz rozwoju technologii może być rozumiane jako kluczowa forma wsparcia dla firm w okresie przejściowym pomiędzy biznesem tradycyjnym i elektronicznym. W ten sposób Cyfrowy Jedwabny Szlak przyczynia się do ułatwiania międzynarodowego handlu elektronicznego. Ponadto jako nierozłączna część inicjatywy Pasa i Szlaku dąży również do poprawy połączeń na całym świecie, zarówno fizycznych, jak i cyfrowych. Wzdłuż Jedwabnego Szlaku jest podejmowanych wiele kroków, które wpływają na usprawnienie globalnego e-handlu. Dzięki umowom o wolnym handlu oraz strefom wolnego handlu firmy mają możliwość zwiększyć efektywność przy jednoczesnej redukcji kosztu oraz czasu dostawy. Co więcej, wykorzystanie zaawansowanych technologii w ramach międzynarodowej współpracy handlowej ma szansę doprowadzić do dalszego ujednolicenia procedur. W efekcie odprawa celna, inspekcja i kwarantanna staną się łatwiejsze i szybsze, co z kolei przełoży się na to, że więcej biznesów będzie w stanie spełnić coraz wyższe wymagania konsumentów.

Inicjatywa Pasa i Szlaku, jak również Cyfrowy Jedwabny Szlak znajdują się we wczesnej fazie rozwoju. Liczne projekty w ramach inicjatywy nie zostały jeszcze ukończone, a wiele porozumień o współpracy i memorandów nie zostało podpisanych lub zrealizowanych. Wpływ obu strategicznych wizji na gospodarkę światową powoli się ujawnia, niemniej potrzebny jest czas, aby mogły ukazać swój prawdziwy potencjał. Do dnia dzisiejszego inicjatywy stworzyły platformę dla firm z całego świata, która pozwala na uczestniczenie w globalnym e-handlu oraz czerpanie korzyści z globalizacji. Nie można jednak zapominać o kontrowersjach wokół chińskiej inicjatywy oraz potencjalnym zagrożeniu płynacym z gospodarczej i cyfrowej ekspansji Chin. Czas pokaże, w jaki sposób i w jakim stopniu Cyfrowy Jedwabny Szlak wpłynie na handel międzynarodowy $\mathrm{i}$ inne aspekty globalnej współpracy.

\section{SUMMARY}

\section{CROSS-BORDER E-COMMERCE ALONG THE DIGITAL SILK ROAD}

Electronic commerce has been developing along with the advancement of the Internet and technology. There have been numerous successes and failures among e-businesses, and one of the main reasons for either scenario is shown to be consumer satisfaction. Data shows that one of the major factors influencing customer experience is related to logistics. Along with the globalization of trade, cross-border e-commerce has brought new challenges that need to be overcome in order to meet the higher requirements of "digital consumers." In 
spite of challenges, global e-commerce nowadays plays an essential role in promoting the development of both economy and industries, including logistics. Recently, global electronic commerce was included in the China-led Belt and Road Initiative, in particular with the Digital Silk Road, which emerged as a result of the initiative merging with the digital economy. This paper aims to explain what the Digital Silk Road refers to and what its relation is with international e-trade. Moreover, it presents an analysis of how the Digital Silk Road supports global e-trade and how cross-border e-commerce influences the Road. This paper forms part of a more thorough study of the role of international electronic commerce in facilitating trade along the Digital Silk Road. 